\title{
The Influence of the Learning Environment on Students' Physical and Mental Health Based on Gender
}

\author{
Ahmad Chaeroni ${ }^{1,2, *}$, Nurlan Kusmaedi², Amung Ma'mun², Dian Budiana ${ }^{2}$, Fahmil Haris ${ }^{1}$ \\ ${ }^{1}$ Department of Health and Recreation, Faculty of Sport Science, Universitas Negeri Padang, Padang, Indonesia \\ ${ }^{2}$ Department of Sports Education, Sekolah Pascasarjana, Universitas Pendidikan Indonesia, Bandung, Indonesia
}

Received March 8, 2021; Revised April 29, 2021; Accepted May 15, 2021

\begin{abstract}
Cite This Paper in the following Citation Styles
(a): [1] Ahmad Chaeroni, Nurlan Kusmaedi, Amung Ma'mun, Dian Budiana, Fahmil Haris, "The Influence of the Learning Environment on Students' Physical and Mental Health Based on Gender," International Journal of Human Movement and Sports Sciences, Vol. 9, No. 4, pp. 622 - 628, 2021. DOI: 10.13189/saj.2021.090403.
\end{abstract}

(b): Ahmad Chaeroni, Nurlan Kusmaedi, Amung Ma'mun, Dian Budiana, Fahmil Haris (2021). The Influence of the Learning Environment on Students' Physical and Mental Health Based on Gender. International Journal of Human Movement and Sports Sciences, 9(4), 622 - 628. DOI: 10.13189/saj.2021.090403.

Copyright $\odot 2021$ by authors, all rights reserved. Authors agree that this article remains permanently open access under the terms of the Creative Commons Attribution License 4.0 International License

\begin{abstract}
The learning environment is a place that has an impact on physical activity so that it affects the level of physical fitness and mental health of students. The purpose of this paper is to determine the impact of the learning environment in urban and rural areas on the physical fitness and mental health of students who are grouped by sex (male and female). A total of 160 students aged 15-18 years are involved in this program, consisting of 80 urban learning environments (40 male and 40 female) and 80 rural learning environments (40 male and 40 female). To determine the level of physical fitness of students measured using the Indonesian Physical Fitness Test (TKJI), while for mental health data were obtained using a questionnaire. Based on the analysis that has been done, there are differences in the physical fitness of students based on the learning environment (urban and rural) in general, rural students are better than urban students. Seen from gender, it proves that the level of physical fitness of rural male students is better than urban men and rural women are better than urban women. Meanwhile, mental health proves that urban students are better than rural students. Based on gender, it proves that the mental health of urban male students is better than that of rural students, while the mental health of urban female students is lower than that of rural students.
\end{abstract}

Keywords Environment, Physical Activity, Physical Fitness, Mental Health

\section{Introduction}

Urban and rural areas are clearly distinguished by their physical characteristics and population density, so that educational settings have different learning environments. The environment is believed to be able to influence physical activity, especially those associated with the environment in which they live and roads that are often traveled [1], and the school environment [2,3]. Urban learning environments tend to be more equipped in terms of facilities than rural environments. However, in terms of area, the physical environment in rural areas is wider than in urban areas. A quiet learning environment is usually felt more in rural areas. The role of the policy of environment, interactions and psychological elements shapes the level of physical activity across various demographic groups [4]. Children in rural learning settings reported a greater likelihood of participating in two or more physical education classes per week [5]. Meanwhile, another opinion states that urban children report more physical activity after school, on holidays and weekends, and also the total amount of physical activity compared to rural children [6]. Thus, more data are needed to corroborate existing findings.

Recent data show that one in four adults (1.4 billion people worldwide) do not meet WHO recommendations on physical activity while providing benefits from a reduced risk of chronic disease and for improving their health and well-being [7]. The prevalence of non-communicable diseases in 2018 has increased when compared to 
Riskesdas 2013, including cancer, stroke, chronic kidney disease, diabetes mellitus, and hypertension. Cancer prevalence increased from $1.4 \%$ (Riskesdas 2013) to $1.8 \%$; the prevalence of stroke increased from $7 \%$ to $10.9 \%$; and chronic kidney disease increased from $2 \%$ to $3.8 \%$. Based on examination of blood sugar, diabetes mellitus increased from $6.9 \%$ to $8.5 \%$; and the results of blood pressure measurement, hypertension rose from $25.8 \%$ to $34.1 \%$ [8]. This proves that there is still low physical activity among Indonesian students which needs serious attention and support to overcome it. Even though it is believed that many physical activities have a good impact on survival.

Physical activity will provide good benefits for the body, especially for: physical fitness $[9,10]$, brain and mental health [11,12], academic achievement [13], motor skills related to skills, coordination and control as the basis for physical activity [14]. Low physical activity has been shown to result in: obesity [15], hipokenetics [16], difficulty solving problems [17]. Endurance and strength physical activity programs can increase life satisfaction for obese children, and even increase satisfaction with aspects of school [18]. This proves that the benefits of physical activity are very important, especially to make students fit and have good mental health. However, the awareness of students to be active still needs intervention from several circles, especially schools and parents.

In a formal learning environment (school), physical education is important in organizing the physical formation process of students. Physical education can be an important source of physical activity for students, especially girls and can influence participation in physical activities outside the classroom [19]. Women $(n=108)$ reported significantly higher exercise and quality of life than men $(n=72)$, women reported exercising to lose weight and toning more than men, whereas men reported exercising for pleasure [20]. Men than women are likely to perform better [21]. There were significant gender differences on all measures of physical fitness, except for partial curl-ups, but no significant gender differences in life satisfaction [22]. Rural residents are less likely to meet 2008 PA guidelines than urban residents ( $42 \%$ versus $51 \%)$, and this trend is replicated among rural men with an impact on physical fitness [23]. Children and adolescents from rural environments showed better results in cardiorespiratory fitness, upper and lower limb muscle fitness and had better coordination, speed, and agility than their urban counterparts [24]. Physical education in schools is generally understood to be able to increase the physical activity of both male and female students which has an impact on physical fitness and mental health, but until now there are still many differences because the results are not consistent, especially in urban and rural areas of Indonesia.

The purpose of this study was to determine the level of physical fitness and mental health among students in urban and rural areas. Furthermore, when viewed from gender, which gender has better physical health and mental health between men and women in urban and rural areas. Based on the information above, each character of the place of education, both in urban and rural areas, has its own strengths and weaknesses, especially in supporting the level of physical and mental health of students. Then if we look in general, how the level of physical fitness and mental health among students in urban and rural areas needs more and more consistent data, in this case it will be reviewed. Furthermore, if it is seen from which gender is better, physical health and mental health between men and women who live in urban and rural areas also need the latest data to support previous findings, especially in Indonesia. The findings of this study will answer the above hypothesis so that it will be the latest findings to support the previous findings.

\section{Methods}

Cities are centers of settlements and resident activities that have administrative boundaries. This is regulated in the Domestic Government Regulation Number 2 of 1987 concerning City Planning Formulation. Whereas the definition of urban in Law Number 26 of 2007 concerning Spatial Planning, urban is an area that has the main activity not agriculture. As for Rural is an area that is within the district environment, in this case in West Sumatra, Indonesia is determined based on regional regulations on the division of areas. Determination of participants based on clusters of students who are in urban and rural schools with an age range of 16-19 years. A total of 160 students were involved in this study consisting of 80 students from urban areas (40 women and 40 men) and 80 students from urban areas ( 40 men and 40 men). To determine the level of physical fitness of students measured using the Indonesian Physical Fitness Test (TKJI) instrument aged 16-19 years consisting of 1) $60 \mathrm{~m}$ sprint, 2) pull-ups (men) and hanging elbows (women), 3) Sit ups, 4 Vertical jump, 5 Medium run (1200m Male \& 1000m Female) [25]. Meanwhile, for mental health using a questionnaire [26]. Data were analyzed by SPSS 16.0. Hypothesis testing is performed using paired sample t-test.

\section{Results}

Based on the analysis carried out on existing data, there are differences in the physical fitness of male students between those in urban and rural areas with a significant value of $0.000<0.05$. The significant value of the independent test Significance value of $0,000<0.05$ there is a difference In general, the average physical fitness level of male adolescent students in rural areas is better than the city, it can be seen that the average value of the village is $18.05>$ the city is 14.23 . as seen in the following table 1 : 
Table 1. Differences in the physical fitness of urban and rural men

\begin{tabular}{cccccc}
\hline & Place & $\mathrm{N}$ & Mean & Std. Deviation & Std. Error Mean \\
\hline \multirow{2}{*}{ TKJI } & Rural & 40 & 18.05 & 2.231 & .344 \\
& Urban & 40 & 14.23 & 2.411 & .371 \\
\hline
\end{tabular}

Based on the table above, the average physical fitness value for rural men is 18.05 , greater than that of urban men, 14.23. Thus it can be concluded that there are significant differences in physical fitness between urban and rural men.

For female sex, the significant difference between urban and rural physical fitness is $0.000<0.05$. The significant value of physical fitness of female adolescent students Significance value of $0,000<0.05$ there is a difference. The difference between the average physical fitness of female adolescents and the average rural area is $13.00>$ greater than that of urban 10.50. as shown in the following table 2:

Table 2. Differences in physical fitness of urban and rural female students

\begin{tabular}{|c|c|c|c|c|c|c|}
\hline & & lace & $\mathrm{N}$ & Mean & $\begin{array}{c}\text { Std. } \\
\text { Deviation }\end{array}$ & $\begin{array}{c}\text { Std. Error } \\
\text { Mean }\end{array}$ \\
\hline \multirow{2}{*}{ TKJI } & \multirow{2}{*}{$\mathrm{d} 1$} & Rural & 40 & 13.00 & 3.170 & .501 \\
\hline & & Urban & 40 & 10.50 & 2.708 & .428 \\
\hline
\end{tabular}

Based on the table above, the average physical fitness value for rural women is 13.00 , greater than that of urban women, 10.50. Thus it can be concluded that there are significant differences in physical fitness between urban women and rural women.

Meanwhile, men's mental health in urban areas was better with an average of 103.53 compared to rural areas of 95.23. as shown in the following table 3:

Table 3. Men's mental health in urban areas

\begin{tabular}{|c|c|c|c|c|c|c|}
\hline & & ace & $\mathrm{N}$ & Mean & $\begin{array}{c}\text { Std. } \\
\text { Deviation }\end{array}$ & $\begin{array}{c}\text { Std. } \\
\text { Error } \\
\text { Mean }\end{array}$ \\
\hline \multirow{2}{*}{ Mental tes } & \multirow{2}{*}{ dl } & Rural & 40 & 95.23 & 7.748 & 1.225 \\
\hline & & Urban & 40 & 103.53 & 6.575 & 1.040 \\
\hline
\end{tabular}

Based on the table above, the average mental health score of urban men is 103.53 , greater than that of rural men, 95.23. Thus it can be concluded that there are significant differences in mental health between urban men and rural men.

The average mental health of urban female adolescent students was 97.38 better than in rural 93.83 . as shown in the following table 4 :

Table 4. Group Statistics

\begin{tabular}{|c|c|c|c|c|c|c|}
\hline & & Place & $\mathrm{N}$ & Mean & $\begin{array}{c}\text { Std. } \\
\text { Deviation }\end{array}$ & $\begin{array}{c}\text { Std. } \\
\text { Error } \\
\text { Mean }\end{array}$ \\
\hline \multirow{2}{*}{$\begin{array}{l}\text { Mental } \\
\text { Test }\end{array}$} & \multirow{2}{*}{ d1 } & Rural & 40 & 97.38 & 6.250 & .988 \\
\hline & & Urban & 40 & 93.83 & 5.913 & .935 \\
\hline
\end{tabular}

Based on the table above, the average mental health score of rural women is 97.38 , greater than that of urban women, which is 93.83 . Thus it can be concluded that there are significant differences in mental health between rural women and urban women.

In general, the physical fitness level of rural adolescent students was better than urban areas with a difference in average $(98.65>60.35)$. as shown in the following table 5 :

Table 5. Combines the differences in the average physical fitness of the urban and rural

\begin{tabular}{ccccc}
\hline & Place & N & Mean Rank & Sum of Ranks \\
\hline \multirow{2}{*}{ TKJI } & Rural & 80 & 98.65 & 7972.00 \\
& Urban & 80 & 60.35 & 4908.00 \\
\hline
\end{tabular}

Based on the table above, the physical fitness of students in rural areas is better with an average score of 98.65 compared to the physical fitness of urban students of 60.35 . Thus it can be concluded that there is a significant difference in the physical fitness of rural students and urban students.

In general, the mental health of adolescent students in urban areas is better than in rural areas (85.93> 73.08). as shown in the following table 6 :

Table 6. Average mental health of urban and rural adolescent students

\begin{tabular}{ccccc}
\hline & Place & N & $\begin{array}{c}\text { Mean } \\
\text { Rank }\end{array}$ & Sum of Ranks \\
\hline \multirow{3}{*}{ Mental tes } & Rural & 80 & 73.08 & 5926.00 \\
& Urban & 80 & 85.93 & 6954.00 \\
\hline
\end{tabular}

Based on the table above, it can be concluded that the Rural score is significantly more than 73.08 while for Urban students it is 85.93 so that there is a significant difference in the level of physical fitness between urban and rural students.

\section{Discussion}

It becomes very interesting by knowing the physical fitness level and health of urban and rural students who are separated by gender. Because the disclosure of the physical fitness sticks and mental health of urban and rural students in Indonesia will be an evaluation and input for educators and policy makers in supporting student growth and development. Physical fitness is an important asset in supporting survival in the future. The results of experimental studies suggest that even small amounts of physical fitness can benefit the health of children at high risk (eg, obesity) [27]. Likewise, in order for the body to be balanced, good mental health is also needed because this is related to one another. Moderate to vigorous physical activity can support good mental health, so it should become a habit to support the development of others [28].

To strengthen data in the field on physical fitness and mental health for both men and women, we reveal based on 
existing findings based on the places where they are, namely urban and rural areas. Urban areas are often the subject of research because of the supportive environmental conditions, for example many universities and government agencies, as well as rural areas that are rarely touched by researchers. Comparing the level of physical fitness and mental health of these two areas is interesting to discuss because each has its own characteristics and characteristics. The findings proved that in general the physical fitness of rural students was better than those in urban areas. This means that students in rural areas are more active in carrying out daily physical activities from moderate to high levels. In addition, rural students are more physically active than playing online games and other sedentary habits. It is different with urban areas which should have been supported by various existing facilities and infrastructure, but students tend to be less active due to busy academic problems and existing technological advances. Therefore, this problem must immediately find the best solution so that urban students are more active in physical activity so that it becomes a support for their physical fitness. Meanwhile, in terms of mental health, students in urban areas are better off than those in rural areas. This is because the maturity of the way of thinking and parental support is their main asset. Moreover, the mediating effects of perceived parental autonomy support and controlling behaviors on children's psychological need satisfaction or frustration, and in turn their activity behaviors will be tested using structural equation modelling methods [29].

If viewed based on gender, the data prove that both men and women in rural areas have better physical health than urban areas. This means that both rural men and women are more active in carrying out their daily physical activities. Because physical activity and lifestyle in rural areas tend to be more energy-intensive activities such as helping the elderly in farming, being active in community sports and the like. It is different with urban students who have more sedentary activities such as studying, academic courses and the like.

One of the goals of national education is how to form a student who has a good personality and physicality or is also called physically and mentally healthy. These two elements are very important in supporting and determining the future of a nation. Health policies aiming at changing physical and mental health need to consider not only the direct cross-effects but also the indirect cross-effects between mental health and physical health [30].The physical fitness of adolescent students in Indonesia should be a serious concern for the government and the wider community. It should be that both rural and urban areas receive the same portion of treatment so that they have the same good level of physical fitness. But what happens is the opposite, this is a common task to solve this problem in the future. Where it was stated that the urban boys and girls produced better physical performance than their rural counterparts [31]. This finding is in line with the results of several previous studies. Children and adolescents from the rural environment show better results in cardiorespiratory fitness, muscle fitness of the upper and lower extremities and have better coordination, speed and agility in comparison with their urban peers [32]. In a study that reported the level of physical activity among rural and urban youths greatly affected their physical fitness [33,34]. Rural boys and girls have higher levels of physical fitness than their urban counterparts. Similar results were previously noted among youth in Spain [35,36].

Health advice is everywhere, but much of it focuses only on the body. As researchers continue to investigate what influences our health, we're finding that physical health and mental health are more closely linked than we realized. If mental or physical health swing out of balance, an individual will suffer. Health advice is everywhere, but much of it focuses only on the body. As researchers continue to investigate what influences our health, we're finding that physical health and mental health are more closely linked than we realized. If mental or physical health swings out of balance, an individual will suffer. Likewise with regard to mental health, both urban and rural adolescent students along with the development of science and technology today have more or less impact on their lives. Rural adolescents are also more affected by their mental health problems. In contrast to previous studies showing that rural and urban youth in Canada experience similar levels of stress [37], our results reveal differences in mental health among young women with urban adolescent dislike. The adolescents' lifestyles showed an increasing trend for physical inactivity in both genders; however, in rural areas, only girls had a rising affinity for a sedentary lifestyle throughout the 2006-2011 years [38].

The physical and mental health of male and female students must have differences and levels are not the same. This finding is supported by previous research which is relevant for further discussion. Gender differences were found for psychological distress, anxiety and depression with girls reporting significantly higher scores than boys [39]. The worst stable infrastructure is associated with negative changes in health for both sexes, with men being more affected by environmental pollution than women [40]. There are gender differences in regular exercise behavior during leisure time and related influential factors among Taiwanese adults [41]. Meanwhile, field findings show that teachers have unconsciously integrated neuroscience in learning, but have never seriously and specifically designed their learning according to the principles of neuroscience-based learning. Researchers suggest developing a neuroscience-based physical education learning model that is based on the found neuroscience learning principles[42]. According to the findings, students' age, year and course of the study influence participation in the universities' physical activity and sports programs. That inadequate sports facility, overcrowded facility, 
unorganized sport programs, lack of sports facility, lack of sports variety, inaccessible facility and lack of coaches were the specific institutional based reasons that influence non-participation in the Kenyan public universities' physical activity and sport programs[43]. This proves that between men and women have their own specificity in the level of physical and mental health.

\section{Conclusion}

Based on the result and discussion that have been done, there are differences in the physical fitness of students based on the learning environment (urban and rural) in general, rural students are better than urban students. Seen from gender, it proves that the level of physical fitness of rural male students is better than urban men and rural women are better than urban women. Meanwhile, mental health proves that urban students are better than rural students. Based on gender, it proves that the mental health of urban male students is better than rural students, while the mental health of urban female students is lower than that of rural students.

\section{Recommendation}

Future research is expected to take several items related to this, including:

- $\quad$ Taking based on the younger age level, for example, the primary school level,

- Upland and lowland areas or based on the humidity level of each area,

- Look at several broader aspects, for example discipline, development of motion, learning outcomes, level of self-confidence and so on.

\section{Acknowledgment}

Our gratitude goes to the Ministry of Education and Culture of the Republic of Indonesia for financing this research process. Furthermore, there are also institutions for teaching and learning, namely the Indonesian education university and Padang State University.

\section{REFERENCES}

[1] Sallis, J. F., Johnson, M. F., Calfas, K. J., Caparosa, S., \& Nichols, J. F. (1997). Assessing Perceived Physical Environmental Variables that May Influence Physical Activity. Research Quarterly for Exercise and Sport, 68(4), 345-351. doi:10.1080/02701367.1997.10608015.

[2] Morton, K. L., Atkin, A. J., Corder, K., Suhrcke, M., \& van Sluijs, E. M. F. (2015). The school environment and adolescent physical activity and sedentary behaviour: a mixed-studies systematic review. Obesity Reviews, 17(2), 142-158. doi:10.1111/obr.12352.

[3] Rezende, L. F. M. de, Azeredo, C. M., Silva, K. S., Claro, R. M., França-Junior, I., Peres, M. F. T., ... Eluf-Neto, J. (2015). The Role of School Environment in Physical Activity among Brazilian Adolescents. PLOS ONE, 10(6), e0131342. doi:10.1371/journal.pone.0131342.

[4] Dollman, J. (2018). Social and Environmental Influences on Physical Activity Behaviours. International Journal of Environmental Research and Public Health, 15(1), 169, doi:10.3390/ijerph15010169.

[5] Dollman, J., Norton, K., \& Tucker, G. (2002) Anthropometry, Fitness and Physical Activity of Urban and Rural South Australian Children. Pediatric Exercise Science, 14(3), 297-312. doi:10.1123/pes.14.3.297.

[6] Sheu-jen, H., Wen-chi, H., Patricia, A. S., \& Jackson, P. W. (2010). Neighborhood environment and physical activity among Urban and Rural Schoolchildren in Taiwan. Health \& Place, 16(3), 470-476. doi:10.1016/j.healthplace.2009.12.0 04.

[7] Guthold, R., Stevens G.A., Riley L.M \& Bull FC. (2018). Worldwide trends in insufficient physical activity from 2001 to 2016: a pooled analysis of 358 population-based surveys with 1. 9 million participants. The Lancet Global Health, 6:10, Pe1077-e1086, doi: 10.1016/s2214-109x(18)30357-7

[8] Depertemen Kesehatan. (2018). Potret Sehat Indonesia dari Risearch kesehatan dasar 2018. Jakarta: Kemenkes.

[9] Berntzen, B., Jukarainen S., Kataja M., Hakkarainen A., Lundbom J., Lundbom N., Tammelin T., Simonen R., Piirilä P., Rissanen A., Kaprio J., Paavonen EJ \& Pietiläinen KH. (2018). Physical activity, cardiorespiratory fitness and metabolic outcomes in monozygotic twin pairs discordant for body mass index. Scandinavian Journal of Medicine \& Science in Sports, 28 (3), 1048-1055. doi: 10.1111/sms.12975.

[10] Potter, M., Spence, J.C., Boulé, N.G., Stearns, J.A \& Carson, V. (2017). Associations between physical activity, screen time, and fitness among 6- to 10-year-old children living in Edmonton, Canada. Applied Physiology, Nutrition, and Metabolism, 42(5), 487-494, doi: 10.1139/apnm-2016-0419.

[11] Kremer, P., Elshaug, C., Leslie, E., Toumbourou, J. W., Patton, G. C., \& Williams, J. (2014). Physical activity, leisure-time screen use and depression among children and young adolescents. Journal of Science and Medicine in Sport, 17(2), 183-187. doi:10.1016/j.jsams.2013.03.012.

[12]Lubans, D., Richards J., Hillman C., Faulkner G., Beauchamp M., Nilsson M., Kelly .P, Smith J., Raine L., Biddle S. (2016). Physical activity for cognitive and mental health in youth: a systematic review of mechanisms. Pediatrics, 138:3. pii: e20161642, doi: 10.1542/peds.2016-1642.

[13] Kari, J.T., Pehkonen J., Hutri-Kähönen N., Raitakari O.T \& Tammelin T.H. (2017). Longitudinal associations between physical activity and educational outcomes. Medicine \& Science in Sports \& Exercise, 49(11), 2158-2166, doi: 10.1249/MSS.0000000000001351.

[14] Barnett, L.M., Lai S.K., Veldman S.L.C., Hardy L.L., Cliff 
D.P., Morgan P.J., Zask A., Lubans D.R., Shultz S.P., Ridgers N.D., Rush E, Brown H.L \& Okely A.D. (2016). Correlates of gross motor competence in children and adolescents: a systematic review and meta-analysis. Sports Medicine. 46(11), 1663-1688, doi: 10.1007/s40279-016-049 5-z.

[15] Nassis, G. P., Klentrou, P., Palmeira, A., \& Stensel, D. J. (2012). The Influence of Physical Activity on Obesity and Health. Journal of Obesity, 1-2. doi:10.1155/2012/298953.

[16] Cardinal, B. J. (2016). Toward a greater understanding of the syndemic nature of hypokinetic diseases. Journal of Exercise Science \& Fitness, 14(2), 54-59. doi:10.1016/j.jesf.2016.07. 001 .

[17] Kao, S.-C., Drollette, E. S., Scudder, M. R., Raine, L. B., Westfall, D. R., Pontifex, M. B., \& Hillman, C. H. (2016). Aerobic Fitness Is Associated With Cognitive Control Strategy in Preadolescent Children. Journal of Motor Behavior, 49(2), 150-162. doi:10.1080/00222895.2016.116 1594.

[18] Budiana, D., Arif, DN., Mudjihartono. (2017). The Effect of Endurance and Strength Physical Activity Program and Nutrition Education to Obesity Children Life Satisfaction. OP Conf. Series: Materials Science and Engineering 180.012194. doi:10.1088/1757-899X/180/1/012194.

[19] Dauenhauer, B. D., \& Keating, X. D. (2011). The Influence of Physical Education on Physical Activity Levels of Urban Elementary Students. Research Quarterly for Exercise and Sport, 82(3), 512-520. doi:10.1080/02701367.2011.105997 84.

[20] Baine B. Craft, Haley A. Carroll, M. Kathleen B. Lustyk (2014). Gender Differences in Exercise Habits and Quality of Life Reports: Assessing the Moderating Effects of Reasons for Exercise. Int J Lib Arts Soc Sci.2(5): 65-76.

[21] Chrismas, B. C. R., Majed, L., \& Kneffel, Z. (2019). Physical fitness and physical self-concept of male and female young adults in Qatar. PLOS ONE, 14(10), e0223359. doi:10.1371/journal.pone.0223359.

[22] Busing, K., \& West, C. (2016). Determining the Relationship Between Physical Fitness, Gender, and Life Satisfaction. SAGE Open, 6(4), 215824401666997. doi:10.1177/2158244 016669974

[23] Benjamin EJ, BlahaMJ, Chiuve SE et al. (2017). Heart disease and stroke statistics-2017 update: a report from the American heart association. Circulation; 135:e146-603.

[24] Sylejmani, B., Myrtaj, N., Maliqi, A., Gontarev, S., Georgiev, G., \& Kalac, R. (2019). Physical fitness in children and adolescents in rural and urban areas. Journal of Human Sport and Exercise, 14(4), 866- 875. doi: https://doi.org/10.14198/ jhse.2019.144.15.

[25] Kemendiknas. (2010).Tes Kesegaran Jasmani Indonesia (TKJI)Usia 16-19 Tahun[Online].

[26] Semiun, Yustinus, (2006), Kesehatan Mental 3, Yogyakarta: Penerbit Kanisius.

[27] Janssen, I., \& LeBlanc, A. G. (2010). Systematic review of the health benefits of physical activity and fitness in school-aged children and youth. International Journal of
Behavioral Nutrition and Physical Activity, 7(1), 40. doi:10.1186/1479-5868-7-40.

[28] Chaeroni.A., Kumaedi.N., Ma'mun. A \& Budiana. D. (2021). Aktivitas Fisik: Apakah Memberikan Dampak Bagi Kebugaran Jasmani Dan Kesehatan Mental?. Jurnal Sporta Saintika Edisi Maret Vol 6 No 1 . DOI: https://doi.org/10.24036/sporta.v6i1.163.

[29] Ha, A. S., Ng, J. Y. Y., Lonsdale, C., Lubans, D. R., \& Ng, F. F. (2019). Promoting physical activity in children through family-based intervention: protocol of the "Active 1 + FUN" randomized controlled trial. BMC Public Health, 19(1). doi:10.1186/s12889-019-6537-3.

[30] Ohrnberger, J., Fichera, E., \& Sutton, M. (2017). The relationship between physical and mental health: $A$ mediation analysis. Social Science \& Medicine, 195, 42-49. doi:10.1016/j.socscimed.2017.11.008.

[31] O.G Eiben, A. Barabas and A.Nemeth. (2005). Comparisn of Growth, Maturation, and Physical Fitness f Hungarian Urban and Rural Boys and Girls.

[32] Sylejmani, B., Myrtaj, N., Maliqi, A., Gontarev, S., Georgiev, G., \& Kalac, R. (2019). Physical fitness in children and adolescents in rural and urban areas. Journal of Human Sport and Exercise, 14(4), 866-875. doi: https://doi.org/10.14198/j hse.2019.144.15.

[33] Davy BM, Harrell K, Stewart J, King DS.(2004). Body weight status, dietary habits, and physical activity levels of middle school-aged children in rural Mississippi. South Med J. ; 97(6): 571- 577.

[34] Paxton RJ, Estabrooks PA, Dzewaltowski D. (2004). Attraction to physical activity mediates the relationship between perceived competence and physical activity in youth. Res Q Exercise Sport; 75(1): 107- 111.

[35] Chillon P., Ortega F. B., Ferrando J. A, Casajus J. A. (2011). Physical fitness in rural and urban children and adolescents from Spain, Journal of Science and Medicine in Sport. , vol. 14 (pg. 417-423).

[36] Albarwani S., Al-Hashmi K., Al-Abri M., Jaju D., Hassan M. O. (2009). Effects of overweight and leisure-time activities on aerobic fitness in urban and rural adolescents, Metabolic Syndrome and Related Disorders, vol. 7 (pg. 369-374) $10.1089 /$ met.2008.0052.

[37] Elgar FJ, Arlett C, Groves R. (2003). Stress, coping, and behavioural problems among rural and urban adolescents. $\mathrm{J}$ Adolesc; 26(5):574-585.

[38] Amiri, P., Naseri, P., Vahedi-Notash, G., Jalali-Farahani, S., Mehrabi, Y., Hamzavi-Zarghani, N., ... Khalili, D. (2020). Trends of low physical activity among Iranian adolescents across urban and rural areas during 2006-2011. Scientific Reports, 10(1). doi:10.1038/s41598-020-78048-0.

[39] Van Droogenbroeck, F., Spruyt, B., \& Keppens, G. (2018). Gender differences in mental health problems among adolescents and the role of social support: results from the Belgian health interview surveys 2008 and 2013. BMC Psychiatry, 18(1). doi:10.1186/s12888-018-1591-4.

[40] Aretz, B., Doblhammer, G., \& Janssen, F. (2019). Effects of changes in living environment on physical health: a 
prospective German cohort study of non-movers. European Journal of Public Health. doi:10.1093/eurpub/ckz044.

[41] Mao H-Y, Hsu H-C, Lee S-D (2020). Gender differences in related influential factors of regular exercise behavior among people in Taiwan in 2007: A cross-sectional study. PLoS ONE15(1):e0228191.https://doi.org/10.1371/journal.pone.0 228191 .
[42] Yusmawati, E. Julianti, and R. H. Purba, "Neuroscience-based physical education learning environment: An analysis," Int. J. Hum. Mov. Sport. Sci., vol. 8, no. 6A, pp. 36-41, 2020, doi: 10.13189/saj.2020.080706.

[43] N. K. Bailasha, E. G. Rintaugu, J. Kamau, F. M. Mwangi, C. M. Mucheke, and M. D. Otieno, "Institutional based reasons for students non-participation in physical activity and sport programs in the Kenyan public universities," Int. J. Hum. Mov. Sport. Sci., vol. 8, no. 1, pp. 17-23, 2020, doi: 10.13189/saj.2020.080102. 